\title{
Biogenic and Risk Elements in Reproductive Organs of Female Cats and Dogs
}

\author{
Peter Massanyi, Nikola Knizatova, Martin Massanyi, Lubomir Pavlik, and Robert Stawarz
}

\begin{abstract}
Study is focused on the concentration of selected elements that affect the living organism as well as individual organs. Samples of uterus and ovaries of dogs and cats were analyzed using absorption spectrometry. The average, minimum and maximum concentrations in the samples were detected and subsequently the correlations between elements were calculated. The average concentration of sodium, potassium, iron and zinc were higher in cats. Higher concentration of calcium and copper were found in the bitch samples. The cadmium concentration in cats was slightly higher compared to bitch. Lead concentrations in the samples of studied cats were $0.28 \pm 0.16 \mathrm{mg} / \mathrm{kg}$ and in female dogs were $0.24 \pm 0.14 \mathrm{mg} / \mathrm{kg}$, mercury concentration reached the $0.01 \pm 0.01 \mathrm{mg} / \mathrm{kg}$ for cats and $0.00 \pm 0.00 \mathrm{mg} / \mathrm{kg}$ for dogs. In cats, a strong negative correlation between sodium and calcium, and a strong positive correlation between the potassium and the calcium and copper and zinc were found. Correlation analysis in female dogs showed strong correlation between sodium and potassium, sodium and copper, potassium and zinc, potassium and cadmium, potassium and lead, iron and mercury, calcium and copper, calcium and mercury, copper and zinc, copper and cadmium as well as the lead and copper and a strong positive correlation between sodium and zinc, sodium and cadmium, sodium and lead, iron and calcium, zinc and cadmium, zinc and lead, and the lead and cadmium. Pets can serve as indicators of environmental metal pollution monitored since as they inhabit the same space as men and are exposed to the same contaminants. Correlations observed for analyzed elements indicate interrelationships of monitored elements in the animal reproductive organs.
\end{abstract}

Index Terms-Sodium, potassium, iron, calcium, copper, zinc, cadmium, lead, mercury, reproductive organs, cat, dog.

\section{INTRODUCTION}

The unrestricted developmental activities such as industrialization and urbanization carried out during the past few decades have given rise to serious problems of environmental pollution [1]. Contamination of the food chain with heavy metals may negatively influence both the health status as well as animal production. Unfavorable effect on the animal health may depend on the kind of the element and its dose as well as on the utility orientation [2].

Lead $(\mathrm{Pb})$ and cadmium $(\mathrm{Cd})$ are important environmental

Manuscript received June 28, 2016; revised September 6, 2016. This work was supported by projects VEGA 1/0760/15, 1/0857/14, APVV-0304-12 and KEGA 006/SPU-4/2015.

P. Massanyi, N. Knizatova, and M. Massanyi are with the Slovak University of Agriculture in Nitra, Department of Animal Physiology, Slovak Republic (e-mail: massanyip@gmail.com).

L. Pavlik is with Private Veterinary Service in Nitra, Slovak Republic and Slovak University of Agriculture in Nitra, Department of Animal Physiology Slovak Republic.

R. Stawarz and P. Massanyi are with Pedagogical University of Krakow, Institute of Biology, Poland. pollutants present in soil, water and air. Their common sources are diverse including natural and anthropogenic processes such as combustion of coal and mineral oil, smelters, mining, as well as paint industries [3]-[6]. Anthropogenic activities and vehicular emissions contribute to the entry of toxic metals to human and animal food chains [7]. $\mathrm{Pb}$ does not have any detectable beneficial biological role. On the contrary, its detrimental effects on physiological, biochemical, and behavioral dysfunctions in animals and humans have been documented by several investigators [8]-[10]. Higher levels affect the central and peripheral nervous system [11], haemopoietic system [12], cardiovascular system [13], kidneys and liver [10]. $\mathrm{Pb}$ and $\mathrm{Cd}$ contamination has also been associated with male reproductive toxicity in experimental animals and has the potential to produce adverse effects on fertility [14]. Pb and $\mathrm{Cd}$-induced tissue damages have been attributed, at least in part, to toxicant-induced oxidative stress [5], [15].

The aim of this study was to determine the concentration of sodium, potassium, iron, calcium, copper, zinc, cadmium, lead and mercury in reproductive organs (ovaries, uterus and fallopian tube) in female cats and dogs and to investigate potential correlations between these elements.

\section{MATERIAL AND METHODS}

\section{A. Material}

Samples were collected during castration and stored at $-20^{\circ} \mathrm{C}$ during assembling. All animals came from Nitra region and at the time of sampling ranged in age from 8 months to 2 years. The majority of individuals were sexually mature and 2 females were pregnant. In the study 11 animals were analyzes, 8 cats and 3 female dogs.

\section{B. Methods}

For mercury analysis $200 \mu \mathrm{L}$ of sample were used in the measurement. Mercury analyzer NIC MA-2 was used. Samples for mercury were not mineralized in the mineralizer (everything was done in the apparatus). Each sample was analyzed twice and if the RSD between replicates was lower than $10 \%$, the mean was calculated and used as the final results. If RSD was higher, the sample was re-analyzed. Quality of the analysis was assessed with CRM and spikes analyses (all recoveries were between 90 and 110\%). Limit of detection $0.1 \mathrm{ng}$; limit of quantification $0.208 \mathrm{ng}$ [16].

For other metals $3 \mathrm{~mL}$ of sample were mineralized with the nitric acid (65\%, Baker Analyzed) in the open mineralization system (VelpScientifica DK20). Mineralized samples were 
diluted up to $10 \mathrm{~mL}$ with the ultrapure water. Then the flame atomic absorption spectrometer was used to quantify the elements (PerkinElmer AAnalyst 200). Each sample was analyzed twice and if the RSD between replicates was lower than $10 \%$, the mean was calculated and used as the final results. If RSD was higher, the sample was re-analyzed. Quality of the analysis was assessed with CRM and spikes analysis (all recoveries were between 90 and 110\%) [17].

\section{Statistics}

The analysis of variance, one-way ANOVA test was realized to calculate basic statistical characteristic and to determine significant differences. Statistical software SAS Release 9.1 (SAS Institute Inc. Cara, USA, 2002-2003) was used. Differences were compared for statistical significance at the level $P<0.05$.

\section{RESULTS AND DISCUSSION}

This study is focused on the concentration of selected elements that affect the living organism as well as individual organs. Total 11 samples of female reproductive organs of dogs and cats were analyzed. The average, minimum and maximum concentrations in the samples were detected and subsequently the correlations between elements were calculated.

The iron in the samples of studied cats was $134.97 \pm 51.23$ $\mathrm{mg} / \mathrm{kg}$ and in female dogs $92.34 \pm 4.10 \mathrm{mg} / \mathrm{kg}$. The average concentration of calcium in the samples of cats reached $15.8 \pm$ $23.62 \mathrm{mg} / \mathrm{kg}$ and in bitch $42.11 \pm 37.70 \mathrm{mg} / \mathrm{kg}$, copper in cat $4.38 \pm 1.59 \mathrm{mg} / \mathrm{kg}$ vs. $\operatorname{dog} 4.50 \pm 0.74 \mathrm{mg} / \mathrm{kg}$, zinc in the cat samples $129.31 \pm 55.81 \mathrm{mg} / \mathrm{kg}$ compared to bitches $126.41 \pm$ $29.15 \mathrm{mg} / \mathrm{kg}$. The average concentration of sodium in the samples of cats was $7648.45 \pm 1589.22 \mathrm{mg} / \mathrm{kg}$ and in bitch $5900.07 \pm 979.51 \mathrm{mg} / \mathrm{kg}$, potassium in cat samples reached $7742.23 \pm 2098.15 \mathrm{mg} / \mathrm{kg}$ and in female dogs $4272.68 \pm$ $1564.19 \mathrm{mg} / \mathrm{kg}$ (Fig. 1).

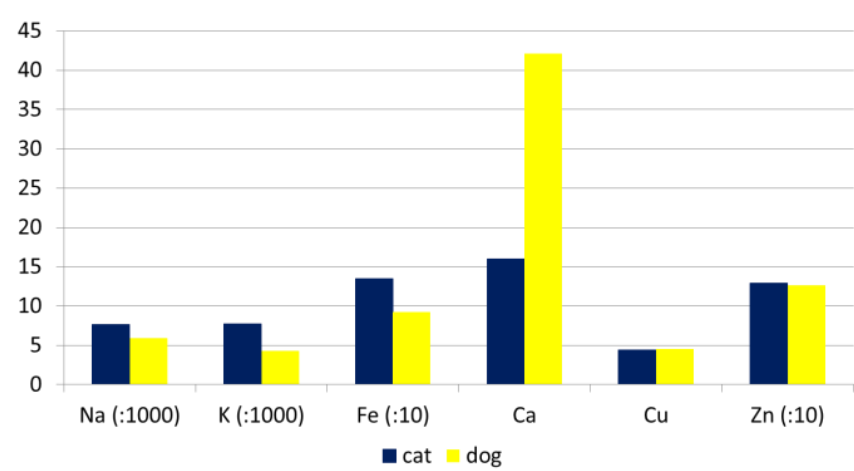

Fig. 1. Biogenic elements $(\mathrm{mg} / \mathrm{kg})$ in female reproductive organs of cats and dogs.

The cadmium concentration in cats was slightly higher $\left(0.32 \pm 0.09 \mathrm{mg} \cdot \mathrm{kg}^{-1}\right)$ compared to bitch $\left(0.27 \pm 0.08 \mathrm{mg} \cdot \mathrm{kg}^{-1}\right)$. Lead concentrations in the samples of studied cats was $0.28 \pm 0.16 \mathrm{mg} \cdot \mathrm{kg}^{-1}$ and in female dogs was $0.24 \pm 0.14 \mathrm{mg} \cdot \mathrm{kg}^{-1}$, mercury concentration reached the $0.01 \pm 0.01 \mathrm{mg} \cdot \mathrm{kg}^{-1}$ for cats and $0.00 \pm 0.00 \mathrm{mg} \cdot \mathrm{kg}^{-1}$ for dogs (Fig. 2).

In cats, a strong negative correlation between sodium and calcium, and a strong positive correlation between the potassium and the calcium and copper and zinc were found
(Table I). Correlation analysis in female dogs showed strong correlation between sodium and potassium, sodium and copper, potassium and zinc, potassium and cadmium, potassium and lead, iron and mercury, calcium and copper, calcium and mercury, copper and zinc, copper and cadmium as well as the lead and copper and a strong positive correlation between sodium and zinc, sodium and cadmium, sodium and lead, iron and calcium, zinc and cadmium, zinc and lead, and the lead and cadmium (Table II).

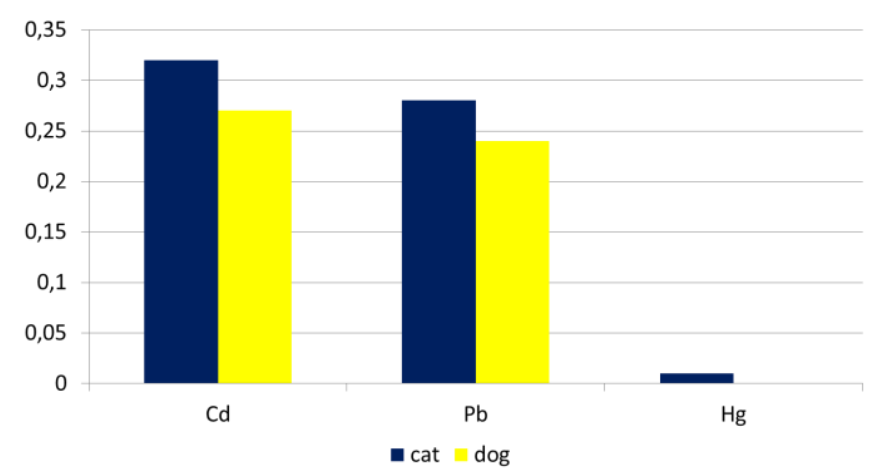

Fig. 2. Xenobiotics $(\mathrm{mg} / \mathrm{kg})$ in female reproductive organs of cats and dogs.

TABLE I: CORRELATIONS BETWEEN ANALYZED ELEMENTS IN CATS

\begin{tabular}{|c|c|c|c|c|c|c|c|c|c|}
\hline & $\mathbf{N a}$ & $\mathbf{K}$ & $\mathbf{F e}$ & $\mathbf{C a}$ & $\mathbf{C u}$ & $\mathbf{Z n}$ & $\mathbf{C d}$ & $\mathbf{P b}$ & $\mathbf{H g}$ \\
\hline $\mathbf{N a}$ & 1.00 & -0.55 & 0.02 & $\mathbf{- 0 . 7 2}$ & -0.49 & -0.63 & -0.07 & -0.27 & -0.60 \\
\hline $\mathbf{K}$ & & 1.00 & 0.03 & 0.43 & $\mathbf{0 . 9 5}$ & 0.21 & 0.42 & 0.48 & 0.65 \\
\hline $\mathbf{F e}$ & & & 1.00 & -0.01 & 0.15 & 0.26 & 0.32 & 0.10 & -0.58 \\
\hline $\mathbf{C a}$ & & & & 1.00 & 0.38 & $\mathbf{0 . 7 5}$ & -0.13 & 0.37 & 0.25 \\
\hline $\mathbf{C u}$ & & & & & 1.00 & 0.35 & 0.46 & 0.38 & 0.55 \\
\hline $\mathbf{Z n}$ & & & & & & 1.00 & -0.09 & 0.16 & 0.09 \\
\hline $\mathbf{C d}$ & & & & & & & 1.00 & -0.39 & 0.19 \\
\hline $\mathbf{P b}$ & & & & & & & & 1.00 & 0.21 \\
\hline $\mathbf{H g}$ & & & & & & & & & 1.00 \\
\hline
\end{tabular}

TABLE II: CORRELATIONS BETWEEN ANALYZED ELEMENTS IN CATS

\begin{tabular}{|c|c|c|c|c|c|c|c|c|c|}
\hline & $\mathbf{N a}$ & $\mathbf{K}$ & $\mathbf{F e}$ & $\mathbf{C a}$ & $\mathbf{C u}$ & $\mathbf{Z n}$ & $\mathbf{C d}$ & $\mathbf{P b}$ & $\mathbf{H g}$ \\
\hline $\mathbf{N a}$ & 1.00 & $\mathbf{- 0 . 8 4}$ & 0.07 & 0.55 & $\mathbf{- 0 . 9 0}$ & $\mathbf{0 . 9 8}$ & $\mathbf{0 . 9 9}$ & $\mathbf{0 . 9 9}$ & 0.00 \\
\hline $\mathbf{K}$ & & 1.00 & 0.59 & -0.02 & 0.52 & $\mathbf{- 0 . 9 3}$ & $\mathbf{- 0 . 8 4}$ & $\mathbf{- 0 . 7 7}$ & -0.54 \\
\hline $\mathbf{F e}$ & & & 1.00 & $\mathbf{0 . 7 9}$ & -0.38 & -0.26 & -0.08 & 0.05 & $\mathbf{- 0 . 9 9}$ \\
\hline $\mathbf{C a}$ & & & & 1.00 & $\mathbf{- 0 . 8 6}$ & 0.38 & 0.55 & 0.65 & $\mathbf{- 0 . 8 3}$ \\
\hline $\mathbf{C u}$ & & & & & 1.00 & $\mathbf{- 0 . 8 0}$ & $\mathbf{0 . 8 9}$ & $\mathbf{- 0 . 9 4}$ & 0.44 \\
\hline $\mathbf{Z n}$ & & & & & & 1.00 & $\mathbf{0 . 9 8}$ & $\mathbf{0 . 9 5}$ & 0.20 \\
\hline $\mathbf{C d}$ & & & & & & & 1.00 & $\mathbf{0 . 9 9}$ & 0.01 \\
\hline $\mathbf{P b}$ & & & & & & & & 1.00 & -0.11 \\
\hline $\mathbf{H g}$ & & & & & & & & & 1.00 \\
\hline
\end{tabular}

Concentration of lead, cadmium and mercury was evaluated in liver and kidney of brown hare in relation to season, age and sex. During a year, an average lead, cadmium and mercury concentrations in studied organs were the highest in winter period. Significantly higher cadmium concentrations in liver and kidney of adult brown hares were detected in comparison with juvenile individuals. Comparison of both sexes determined higher lead concentration in males in comparison with females as well as significantly higher cadmium concentration in females in comparison with male brown hares [18]-[20].

Furthermore, in experiment the accumulation of cadmium in selected organs of animals was studied. After a single intra peritoneal cadmium administration the highest concentration were found in liver, followed by kidneys, ovaries, uterus, 
muscle and testes. After a daily per oral cadmium administration for 5 month the highest cadmium concentration was detected in kidney, followed by liver, ovaries, uterus, muscle and testes. Also the cadmium concentration in bovine ovaries, oviduct, uterus, testis and tunica albuginea of testis were analyzed. Surprisingly, the highest cadmium concentration was detected in oviduct. The concentration of cadmium in male reproductive organs was lower in comparison with females [21], [22].

After a cadmium administration changes in the number of follicles with less than 2 layers as well as more than 2 layers of follicular (granulosa) cells and antral follicles were detected. The number of atretic follicles was significantly higher in all experimental groups with cadmium administration. The relative volume of growing follicles was significantly decreased and that of stroma significantly increased in experimental groups compared to control, directly suggesting the effect of cadmium on folliculogenesis. In comparison with ovaries, alterations detected in oviduct and uterus was weaker In uterus rapid oedematization occurs caused by the blood vessel dilatation, vessel wall disarrangement and subsequent diapedesis. In detail study the effect of cadmium on the rabbit ovarian cell ultrastructure was examined. Qualitative analysis determined undulation of nuclear membrane, dilated perinuclear cistern and endoplasmic reticulum. Qualitative analysis proved alterations in various cell structures. Similar ultrastructural alterations were also found in oviduct and uterus. In Japanese quails estimation of the number of follicles undergoing atresia found significantly increased number of atretic primary as well as growing follicles in the group with cadmium administration and in the group with cadmium + selenium co-administration in comparison with control group. Co-administration of selenium showed protective effect, but only the co-administration of zinc prevents significant ovarian changes. Obtained data of in vitro experiments were confirmed also in in vitro conditions. The results of these studies proved negative effect of cadmium on the ovarian structure on the level of light as well as electron microscopy [23]-[29].

After experimental cadmium administration to mice dose dependent accumulation of cadmium in testes was found. Morphometric analysis detected weak decrease of germinal epithelium and increased relative volume of interstitium. Also a decrease of seminiferous tubule diameter was observed. Concentration of $\beta$-carotene significantly decreased in both experimental groups, whereas the concentration of retinyl palmitate and retinol decreased only in the group with the higher cadmium dose. In rabbits experimental cadmium administration resulted in significant decrease of germinal epithelium and significant increase of interstitium in comparison with control. Germinal epithelium showed signs of alterations, with changes in basal membrane. After a lead and mercury administration to rats, dilatation of blood capillaries in interstitium, undulation of basal membrane and occurrence of empty spaces in seminiferous (germinal) epithelium of testis was observed. Apoptosis detection confirmed higher occurrence of apoptosis of spermatogenic cells. Detail morphometric analysis detected significant difference in evaluated parameters in experimental animals compared to control ones. After a nickel administration to mice a significant decrease of relative volume of germinal epithelium in comparison with control was found. TUNEL analysis confirmed significantly increased apoptosis in interstitium of animals after a nickel administration compared to control. Similar alterations cause also the cobalt administration. In in vitro conditions the effect of nickel on the structure and function of Leydig cells was studied. Testosterone production decrease even at the lower nickel concentration and subsequently linearly to the increasing nickel concentrations. Apoptosis visualization using TUNEL method detected higher percentage of apoptotic cells in experimental groups also up to $100 \%$. Most significant cell vacuolization was detected in the group with the highest nickel concentration in medium [30]-[37].

\section{CONCLUSION}

Study is focused on the concentration of selected elements that affect the living organism as well as individual organs. The average concentration of sodium, potassium, iron and zinc were higher in cats. Higher concentration of calcium and copper were found in the bitch samples. The cadmium concentration in cats was slightly higher compared to bitch. Pets can serve as indicators of environmental metal pollution monitored since as they inhabit the same space as men and are exposed to the same contaminants. Correlations observed for analyzed elements indicate interrelationships of monitored elements in the animal reproductive organs.

\section{ACKNOWLEDGMENT}

This study was supported by projects VEGA 1/0760/15, 1/0857/14, APVV-0304-12, APVV-15-0543, APVV-140637 and KEGA 006/SPU-4/2015.

\section{REFERENCES}

[1] R. Azmat, R. Parveen, I. I. Naqvi, and S. Shoukat, "Effect of Cr (III) combine with atrazine on protein, carbohydrate, amino acid and chlorophyll content in Vigna radita (L.) Wilczek," International Journal of Biology and Biotechnology, vol. 2, no. 2, pp. 433-439, 2005.

[2] J. Slivkova, P. Massanyi, F. Pizzi, J. Trandzik, S. Roychoudhury, N. Lukac, M. Dankova, and V. Almasiova, "In vitro toxicity of mercuric chloride on rabbit spermatozoa motility and cell membrane integrity," Journal of Environmental Science and Health, vol. A45, pp. 767-774, 2010.

[3] C. Phillips, Z. Gyori, and B. Kovacs, "The effect of adding cadmium and lead alone or in combination to the diet of pigs on their growth, carcase composition and reproduction," Journal of Science in Food Agriculture, vol. 83, no. 13, pp. 1357-1365, 2003.

[4] R. C. Patra, D. Swarup, R. Naresh, P. Kumar, P. Shekhar, and R. Ranjan, "Cadmium level in blood and milk from animals reared around different polluting sources in India," Bulletin of Environmental Contamination and Toxicology, vol. 74, no. 6, pp. 1092-1097, 2005.

[5] R. C. Patra, A. K. Rautray, and D. Swarup, "Oxidative stress in lead and cadmium toxicity and its amelioration," Veterinary Medicine International, vol. 23, no. 3, pp. 27-34, 2011.

[6] R. C. Patra, D. Swarup, R. Naresh, P. Kumar, D. Nandi, P. Shekhar, S. Roy, and S. L. Ali, "Tail hair as an indicator of environmental exposure of cows to lead and cadmium in different industrial areas," Ecotoxicology and Environmental Safety, vol. 66, no. 1, pp. 127-131, 2007.

[7] I. A. Okada, A. M. Sakuma, F. D. Maid, S. Dovidemskas, and O. Zenebon, "Evaluation of lead and cadmium in milk due to environmental contamination in Paraiba valley region of South Eastern Brazil," Raissade-Saude-Publica, vol. 31, pp. 140-143, 1997. 
[8] H. A. Ruff, M. E. Markowitz, P. E. Bijur, and J. F. Rosen, "Relationships among blood lead levels, iron deficiency, and cognitive development in two-year-old children," Environmental Health Perspectives, vol. 104, no. 2, pp. 180-185, 1996.

[9] T. Kaji, "Cell biology of heavy metal toxicity in vascular tissue," Yakugaku Zasshi, vol. 5, pp. 245-250, 2004.

[10] M. Kramarova, P. Massanyi, J. Slamecka, F. Tataruch, A. Jancova, J. Gasparik, M. Fabis, J. Kovacik, R. Toman, J. Galova, and R. Jurcik, "Distribution of cadmium and lead in liver and kidneys of some wild animals in Slovakia," Journal of Environmental Science and Health, vol. A40, pp. 593-600, 2005.

[11] J. Dressier, K. A. Kim, T. Chakraborti, and G. Goldstein, "Molecular mechanisms of lead neurotoxicity," Neurochemical Research, vol. 24 no. 4, pp. 595-600, 1999.

[12] P. E. Silva, "Determination of lead in plasma and studies on its relationship to lead in erythrocytes," Brazilian Journal of Medicine, vol. 38 , pp. 209-217, 1981

[13] F. Khalil-Manesh, H. C. Gonick, E. W. J. Weiler, B. Prins, M. A. Weber, and R. E. Purdy, "Lead-induced hypertension: possible role of endothelial factors," American Journal of Hypertension, vol. 6, no. 9, pp. 723-729, 1993.

[14] M. V. Rao and P. S. Sharma, "Protective effect of vitamin E against mercuric chloride reproductive toxicity in male mice," Reproductive Toxicology, vol. 15, pp. 705-712, 2001.

[15] R. C. Patra, D. Swarup, and S. K. Dwivedi, “Antioxidant effects of $\alpha$ tocopherol, ascorbic acid and L-methionine on lead induced oxidative stress to the liver, kidney and brain in rats," Toxicology, vol. 162, no. 2 , pp. 81-88, 2001.

[16] L. J. Binkowski, D. Merta, A. Przystupinska, Z. Soltysiak, J. Pacon, and R. Stawarz, "Levels of metals in kidney, liver and muscle tissue and their relation to the occurrence of parasites in the red fox in the Lower Silesian Forest in Europe," Chemosphere, vol. 149, pp. 161-167, 2016.

[17] M. Janicka, L. J. Binkowski, M. Błaszczyk, J. Paluch, W. Wojtas, P. Massanyi, and R. Stawarz, "Cadmium, lead and mercury concentrations and their influence on morphological parameters in blood donors from different age groups from southern Poland," Journal of Trace Elements in Medicine and Biology, vol. 29, pp. 342-346, 2015.

[18] P. Massanyi, F. Tataruch, J. Slamecka, R. Toman, and R. Jurcik, "Accumulation of lead, cadmium, and mercury in liver and kidney of the brown hare (Lepus europaeus) in relation to the season, age, and sex in the west Slovakian lowland," Journal of Environmental Science and Health, vol. A38, p. 1299-1309, 2003.

[19] R. Toman and P. Massanyi, P, "Cadmium in selected organs of fallow-deer (Dama dama), sheep (Ovis aries), brown hare (Lepus europaeus) and rabbit (Oryctologus cuniculus) in Slovakia," Journal of Environmental Science and Health, vol. A31, p. 1043-1051, 1996.

[20] P. Massanyi, R. Toman, V. Uhrin, and P. Renon, "Distribution of cadmium in selected organs of rabbits after an acute and chronic administration." Italian Journal of Food Sciences, vol. 7, pp. 311-316, 1995.

[21] P Massanyi, L. Bardos, K. Oppel, S. Hluchy, J. Kovacik, G. Csicsai, and R. Toman, "Distribution of cadmium in selected organs of mice: Effects of cadmium on organ contents of retinoids and $\beta$-carotene," Acta Physiologica Hungarica, vol. 86, pp. 99-104, 1999.

[22] P. Massanyi, R. Toman, and F. Najmik, "Concentrations of cadmium in ovary, oviduct, uterus, testis and tunica albuginea of testis in cattle," Journal of Environmental Science and Health, vol. A30, pp. 1685-1692, 1995.

[23] P. Massanyi and V. Uhrín, "Histological changes in the ovaries of rabbits after an administration of cadmium," Reproduction in Domestic Animals, vol. 4-5, pp. 629-632, 1996.

[24] P. Massanyi, V. Uhrin, R. Toman, J. Kovacik, and D. Biro, "Histological changes in the oviduct of rabbits after administration of cadmium," Journal of Animal and Feed Sciences, vol. 8, pp. 255-261, 1999.

[25] P. Massanyi and V. Uhrin, "Histological changes in the uterus of rabbits after an administration of cadmium," Journal of Environmental Science and Health, vol. A32, pp. 1459-1466, 1997.

[26] P. Massanyi, V. Uhrin, R. Toman, J. Pivko, N. Lukac, Z. Forgacs, Z. Somosy, M. Fabis, and J. Danko, "Ultrastructural changes of ovaries in rabbits following cadmium administration," Acta Veterinaria Brno, vol. 74, pp. 29-35, 2005.

[27] P. Massanyi, N. Lukac, V. Uhrin, R. Toman, J. Pivko, J. Rafay, Z Forgacs, and Z. Somosy, "Female reproductive toxicology of cadmium," Acta Biologica Hungarica, vol. 58, pp. 287-299, 2007.

[28] P. Nad, P. Massanyi, M. Skalicka, B. Korenekova, V. Cigankova, and V. Almasiova, "The effect of cadmium in combination with zinc and selenium on ovarian structure in Japanese quails," Journal of Environmental Science and Health, vol. A42, pp. 2017-2022, 2007.

[29] P. Massanyi, V. Uhrin, A. V. Sirotkin, K. Paksy, Z. Forgacs, R. Toman, and J. Kovacik, "Effects of cadmium on ultrastructure and steroidogenesis in cultured porcine ovarian granulosa cells," Acta Veterinaria Brno, vol. 69, pp. 101-106, 2000.

[30] P. Massanyi, Z. Kiss, R. Toman, and L. Bardos, "Effect of acute cadmium exposure on testicular tissue and testicular retinoid and $\beta$-carotene content," Magyar Allatorvosok Lapja, vol. 124, pp 688-692, 2002.

[31] R. Toman, P. Massanyi, and V. Uhrin, "Changes in the testis and epididymis of rabbits after an intraperitoneal and peroral administration of cadmium," Trace Elements and Electrolytes, vol. 19, pp. 114-117, 2002

[32] P. Massanyi, N. Lukac, A. V. Makarevich, P. Chrenek, Z. Forgacs, M. Zakrzewski, R. Stawarz, R. Toman, P. Lazor, and S. Flesarova, "Lead-induced alterations in rat kidney and testes in vivo," Journal of Environmental Science and Health, vol. A42, pp. 671-676, 2007.

[33] P. Massanyi, N. Lukac, J. Slivkova, J. Kovacik, A. V. Makarevich, P. Chrenek, R. Toman, Z. Forgacs, Z. Somosy, R. Stawarz, and G. Formicki, "Mercury-induced alteration in rat kidney and testes in vivo," Journal of Environmental Science and Health, vol. A42, pp. 865-870, 2007.

[34] P. Massanyi, N. Lukac, J. Zemanova, A. V. Makarevich, P. Chrenek, V. Cigankova, S. Flesarova, R. Toman, Z. Forgacs, Z. Somosy, and P. Lazor, "Effect of nickel administration in vivo on the testicular structure in mice," Acta Veterinaria Brno, vol. 76, pp. 223-229, 2007.

[35] N. Lukac, P. Massanyi, M. Zakrzewski, R. Toman, V. Cigankova, and R. Stawarz, "Cobalt-induced alterations in hamster testis in vivo," Journal of Environmental Science and Health, vol. A42, pp. 389-392, 2007.

[36] J. Slivkova, P. Massanyi, F. Pizzi, J. Trandzik, S. Roychoudhury, N. Lukac, M. Dankova, and V. Almasiova, "In vitro toxicity of mercury chloride on rabbit spermatozoa motility and cell membrane integrity," Journal of Environmental Science and Health, vol. A45, pp. 767-774, 2010.

[37] S. Roychoudhury, P. Massanyi, J. Bulla, M. D. Choudhury, N. Lukac, T. Filipejova, J. Trandzik, R. Toman, and V. Almasiova, "Cadmium toxicity at low concentrations on rabbit spermatozoa motility, morphology and membrane integrity in vitro," Journal of Environmental Science and Health, vol. A45, pp. 1374-1383, 2010.

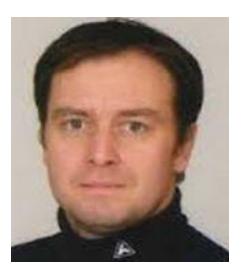

Peter Massanyi was born in 1968 in Nitra, Czechoslovakia. He is the head of the Department of Animals Physiology, Faculty of Biotechnology and Food Sciences, Slovak University of Agriculture in Nitra. In 1991 P. Massanyi obtained the D.V.M (MVDr.) title at the University of Veterinary Medicine, Kosice, Czechoslovakia (General Veterinary Medicine), in $1996 \mathrm{Ph} . \mathrm{D}$. degree at the University of Agriculture, Nitra (General Animal Production), in 2000 became Associated Professor, Slovak University of Agriculture, Nitra (General Animal Production), in 2011 Professor at the Constantine the Philosopher University, Nitra (Biology) and in 2011 obtained the DrSc. (DSc.) degree at the Slovak University of Agriculture (General Animal Production). Other information and list of publication is available at: https://sites.google.com/site/massanyip/cv

Lubomir Pavlik is a private veterinarian with many years of excellent practice also closely cooperating with Slovak University of Agriculture in Nitra, Department of Animal Physiology.

Robert Stawarz was born in 1966 in Poland. He is the vice-rector of Pedagogical University of Krakow and working in the field of biology at the Pedagogical University of Krakow, Institute of Biology. 